RESEARCH Note

\title{
Concentration and distribution of macrominerals in tissues of Mediterranean mussel Mytilus galloprovincialis exposed to $\mathrm{Cd}$ and $\mathrm{Cd}$-mixtures
}

\author{
Concentración y distribución de macrominerales en tejidos de mejillón del \\ Mediterráneo Mytilus galloprovincialis expuesto a $\mathrm{Cd}$ y a mezclas de $\mathrm{Cd}$
}

\author{
José A. García-Navarro ${ }^{1}$, Miguel A. Vera-Sánchez ${ }^{1}$ and Diego Romero (1) $^{*}$ \\ 'Área de Toxicología, Facultad de Veterinaria, Universidad de Murcia, Campus Regional de Excelencia Internacional “Campus Mare \\ Nostrum", Espinardo, E-30071, Murcia, España \\ *Corresponding author: diegorom@um.es
}

\begin{abstract}
Marine ecosystems are under great pressure due to heavy metals pollution, and mussels remain an important knowledge source in this regard. In this study, Mediterranean mussels (Mytilus galloprovincialis) were exposed for 7 days to $\mathrm{Cd}$ and three $\mathrm{Cd}$ mixtures $(\mathrm{Cd}+\mathrm{Pb}, \mathrm{Cd}+\mathrm{Cu}$ and $\mathrm{Cd}+\mathrm{Pb}+\mathrm{Cu})$. The accumulation and tissue distribution of inorganic elements $(\mathrm{Ca}, \mathrm{K}, \mathrm{Mg}, \mathrm{Na}, \mathrm{P}$ and $\mathrm{S}$, macrominerals) that are usually not taken into consideration in field studies on in bioassays were evaluated. Regarding concentration, the element which differed the most with respect to the control group was $\mathrm{K}$, while Mg was the only one which showed no significant statistical difference with the control group. The group exposed to ternary mixture was the one in which there were more alterations in concentration and distribution of these macrominerals with respect to control, whereas in the group exposed to single $\mathrm{Cd}$ no significant differences in the concentration of these inorganic elements were found. The concentration and distribution of macrominerals in the compartments studied (digestive gland, gill and remaining soft tissues) is susceptible to the presence of $\mathrm{Cd}$ and heavy metal $\mathrm{Cd}$-mixtures, with percentages of changes until $28.7 \%$. Study results suggest that macrominerals composition in mussel tissues could be useful in studies of heavy metal contamination in marine ecosystems.
\end{abstract}

Key words: Accumulation, distribution, heavy metals, macrominerals, mussels

\section{INTRODUCTION}

All living beings use inorganic elements (metals, no metals and metalloids) for the normal development of their biological processes, so they are commonly referred to as "essential minerals". They are necessary components both for the proper growth of the organism and its reproduction and, therefore, fundamental to the maintenance of a good health throughout life, regardless of the animal species concerned. Hence, many are the functions in which their participation has been described: they act as structural components in organs and tissues, serve as electrolytes in body fluids and act as catalysts in enzymatic and endocrine systems. Calcium $(\mathrm{Ca})$, phosphorus $(\mathrm{P})$, potassium $(\mathrm{K})$, magnesium $(\mathrm{Mg})$, sodium $(\mathrm{Na})$ and sulfur $(\mathrm{S})$ are considered as macrominerals, since the organisms need high amount of them (McDowell 2003, Fraga 2005).

In marine organisms, the corporal concentration of these macrominerals depends on multiple factors, as the feeding source, the quality of the environment and the species, as well as the development phase and physiological state (Lall 2002). Marine invertebrates have important amounts of elements such as Ca or K (Taboada et al. 2008), being important the participation of macrominerals in many functions, as the formation of body structures (shells and exoskeleton), the acid-base balance, muscular function and enzymatic activity, inter alia (Muneoka \& Twarog 1983, Wilbur \& Saleuddin 1983, Simkiss \& Wilbur 1989, Rosenberg \& Hughes 1991, Korchagin 1995, Klein et al. 1996, Lucu \& Towle 2003, Li et al. 2004). In general, an excess or lack of these elements, although essentials, can cause biochemical defects, alteration of the physiological functions and structural disturbances (McDowell 2003, Pond et al. 2005). Therefore, knowledge concerning mineral concentrations in living organisms has vital importance for a better understanding of the relationship among chemical elements and living beings, as well as for understanding the link between health status and environmental exposure problems (Iyengar 1989). 
Heavy metals cause numerous ecological effects on marine ecosystems, as well as a high public concern about food security (Wang et al. 2005, Rainbow 2007, Feng et al. 2008, Wang \& Rainbow 2008, Lin et al. 2013), especially if they are present at levels above the toxicity thresholds (Macdonald et al. 1996, O’Connor 2004). But the environmental risk from pollution is the result of the toxicity of pollutant's mixtures, sometimes very complex. Considering that the effect of exposure to a metal on the accumulation of other inorganic elements has been scarcely documented (Regoli \& Principato 1995, Serra et al. 1999), the aim of this study has been to know the influence of the exposure to heavy metals ( $\mathrm{Cd}$ and $\mathrm{Cd}$-mixtures, with $\mathrm{Pb}$ and $\mathrm{Cu}$ ) on the accumulation and tissue distribution of macrominerals in the Mediterranean mussel Mytilus galloprovincialis (Lamarck, 1819) for digestive gland, gills and remaining soft tissues.

\section{Materials AND METHODS}

\section{MUSSEL COLLECTION AND CONDITIONING PERIOD}

Mediterranean mussels (M. galloprovincialis), with 4-5 $\mathrm{cm}$ in length and 9-10 $\mathrm{g}$ in weight, were collected at Cabo Home (Galicia, NW Spain) (geographic reference $42^{\circ} 15.007 ; 08^{\circ} 52.333$ ), an uncontaminated location without local assets of pollutants (Albentosa et al. 2012, Besada et al. 2014, González-Fernández et al. 2015). Mussels were adjusted for two weeks under laboratory-managed water $\mathrm{pH}(8.03 \pm 0.07)$, osmolarity $(1086.3 \pm 28.39 \mathrm{mmol}$ $\left.\mathrm{kg}^{-1}\right)$, temperature $\left(24^{\circ} \mathrm{C}\right)$, non-stop aeration and natural photoperiod conditions. After two days to acclimatization, mussels were fed with the microalgae Isochrysis galbana, clone t-ISO $(0.1 \%$ of microalgal organic matter per mussel live weight).

\section{HEAVY METAL EXPOSURE}

Mussels were exposed to single $(\mathrm{Cd})$, binary $(\mathrm{Cd}+\mathrm{Pb}$ and $\mathrm{Cd}+\mathrm{Cu})$ and ternary $(\mathrm{Cd}+\mathrm{Pb}+\mathrm{Cu})$ mixtures at entire doses of $100 \mu \mathrm{g} \mathrm{L}^{-1}(\mathrm{Cd}$ and $\mathrm{Cu})$ and $1000 \mu \mathrm{g} \mathrm{L}^{-1}(\mathrm{~Pb})$. The test was carried in three tanks per treatment, with 12 mussels every ( $n=36$ mussels per exposure group) throughout seven days; then, a complete of nine mussels per treatment had been randomly selected for macrominerals analysis. A control group of $n=36$ non-exposed mussels was additionally set up (three tanks with 12 mussels each). Heavy metal stock solutions $\left[\mathrm{Pb}\left(\mathrm{NO}_{3}\right)_{2}, \mathrm{CdCl}_{2}\right.$ and $\left.\mathrm{CuSO}_{4}\right]$ were prepared in milliQ water. In the course of the exposure time, temperature, $\mathrm{pH}$, osmolarity, photoperiod, aeration and feeding conditions have been controlled as defined above, and no mussels died.
The dose of the heavy metals was adjusted in artificial sea water and then, it was introduced every day to each tank. The real (final) concentrations of metals in water were 933.69 $\pm 84.66 \mu \mathrm{g} \mathrm{L}^{-1}(\mathrm{~Pb}), 83.39 \pm 10.44 \mu \mathrm{g} \mathrm{L}^{-1}(\mathrm{Cd})$ and 82.40 $\pm 4.83 \mu \mathrm{g} \mathrm{L}^{-1}(\mathrm{Cu})$.

\section{SAMPLE COLLECTION AND PROCESSING}

Prior to sampling, mussels were slightly opened, and washed with double distilled water. Next, the mussels were kept on blotting paper to remove the internal water. After $5 \mathrm{~min}$, gills, the digestive gland and the remaining of the soft tissues -labeled as RST- were cautiously separated from every mussel, weighed and frozen at $-80{ }^{\circ} \mathrm{C}$ until analysis. Overall soft tissue (OST) was computed using information from all the specific organs.

\section{Metal analysis}

Samples were analysed using inductively coupled plasma optical emission spectrometry (ICP-OES, ICAP 6500 Duo, Thermo Scientific, with One Fast System) to find out macrominerals ( $\mathrm{Ca}, \mathrm{K}, \mathrm{Mg}, \mathrm{Na}, \mathrm{P}$ and $\mathrm{S}$ ) contents. Gills, the digestive gland and RST were treated with trace mineral grade nitric acid (69\% Suprapure, Merck $\left.{ }^{\circledR}\right)$ and $33 \% \mathrm{H}_{2} \mathrm{O}_{2}$ (Suprapure, Merck ${ }^{\circledR}$ ) in special Teflon reaction tubes, heated in a microwave digestion system (UltraClave-Microwave Milestone ${ }^{\circledR}$ ) for $20 \mathrm{~min}$ at $220^{\circ} \mathrm{C}$, and finally diluted to $25 \mathrm{~mL}$ with double deionised water (MilliQ). The detection limit for the analysed elements was $0.001 \mu \mathrm{g} \mathrm{g}^{-1}$. Two readings for every sample were performed and concentration values were used as the mean of both readings. To check for possible contaminants, one blank sample for every 11 samples was also analysed. Multi-element calibration standards (SCP Science, in 4\% nitric acid) were prepared with specific concentrations of inorganic elements, taking as a reference UNE-EN ISO 11885 (UNE 2021) ${ }^{1}$ for the determination of elements by inductively coupled plasma atomic emission spectroscopy. Furthermore, intermediate patterns of all elements were prepared. The calibration device was established per batch with a minimum of three points for every single lot. Each run started out with the calibration standards, continued with samples and intermediate patterns, and finished with the series with intermediate patterns $(10 \%$ variation coefficient). The wavelengths (nm) were 184.006/315.887 (Ca), $766.490(\mathrm{~K}), 202.582 / 279.079(\mathrm{Mg}), 589.592(\mathrm{Na})$, $185.942 / 213.618 / 214.914(\mathrm{P})$ and $180.731 / 182.034(\mathrm{~S})$. The uncertainty percentages of the elements were 4.34 (Ca), $4.56(\mathrm{~K}), 4.70(\mathrm{Mg}), 5.23(\mathrm{Na}), 3.45(\mathrm{P})$ and $4.25(\mathrm{~S})$.

${ }^{1}$ UNE-EN ISO 11885:2010. Calidad del agua. Determinación de elementos seleccionados por espectrometría de emisión óptica de plasma acoplado inductivamente (ICP-OES) (ISO 11885:2007). Asociación Española de Normalización (UNE), Madrid. <https://www.une.org/encuentra-tu-norma/ busca-tu-norma/norma/?c=N0044517> 
The recovery for reference materials was $94.34(\mathrm{Ca}), 94.56$ (K), $94.70(\mathrm{Mg}), 95.23(\mathrm{Na}), 93.45(\mathrm{P})$ and $104.25(\mathrm{~S})$. All concentrations are expressed in microgram per gram in wet weight (ww).

\section{Data ANALYsis}

The statistics given for the macromineral concentrations and weight of soft tissue are geometric mean and standard error. Overall soft tissue concentrations were determined from the data (metal concentration and tissue weight) of gills, the digestive gland and RST. A Shapiro-Wilk test was used to check the data distribution. According to this distribution, Mann-Whitney $U$ and t-Student tests were employed to compare $\mathrm{Cd}$ and $\mathrm{Cd}$-mixture groups with respect to control group, and Kruskal-Wallis one-way ANOVA test to compare exposure groups between them. The weight of the tissues was checked with Kruskal-Wallis test. The significance level for each test was set as 0.05. All statistical analyses were accomplished with SPSS ${ }^{\circledR}$ v.24.0 for Windows (SPSS Inc., Chicago, IL, USA).

\section{RESULTS AND DISCUSSION}

There are several reasons to study the possible variations in mineral concentrations in soft tissues from mussels exposed to heavy metals. On the one hand, a recent study on Mytilus edulis and Perna viridis show a great variability in macronutrients $(\mathrm{C}, \mathrm{N}, \mathrm{P}, \mathrm{S})$ and large cations $(\mathrm{Na}, \mathrm{Mg}, \mathrm{K}$, $\mathrm{Ca}$ ) in their tissues, as well as their potential relationship with the bioaccumulation of different trace elements, among which $\mathrm{Pb}, \mathrm{Cd}$ and $\mathrm{Cu}$ are cited (Liu \& Wang 2015). On the other hand, in many aquatic organisms have been described, among chemically similar cations, competitive effects by the sites of absorption and union (Hinkle et al. 1987, Blažka \& Shaikh 1991, Roesijadi \& Unger 1993, Di Toro et al. 2001), as well as the possibility of sharing similar metabolic pathways (Liu et al. 2012). Besides, some elements such as those used in this study are able to bind cell membranes and obstruct natural processes of transport across the cell wall (Boran \& Altinok 2010). In their natural environment, marine organisms are simultaneously exposed to complex mixtures of metals. Although there is a lot of experimental evidence on interactions among elements (Popham \& D'Auria 1982, Calabrese et al. 1984, Blackmore \& Wang 2002, Fraysse et al. 2002), the physiological and biochemical mechanisms that underlie this interaction still remain not well explained (Shi \& Wang 2004).

\section{CONTROL GROUP}

Regarding tissue weight, there were no statistical differences between exposure groups (Table 1). In all analysed tissues as well as in OST (Table 2), the element which was in a higher concentration was $\mathrm{Na}$, followed by $\mathrm{S}$ and $\mathrm{K}$. Except in the digestive gland, $\mathrm{Ca}$ was the element of control group which was in lower concentration, being similar the concentrations of $\mathrm{P}$ and $\mathrm{Mg}$ in RST and OST. Although some authors show some similarities with this order in the same species (e.g., higher $\mathrm{Na}$ and lower $\mathrm{Ca}$ concentrations, Fuentes et al. 2009, Bongiorno et al. 2015; S $>\mathrm{K}>\mathrm{Ca}$, Jović et al. 2011, Santos et al. 2014), other studies show certain differences, associated to the bivalve species, geographical area and season of the year (e.g., $\mathrm{Ca}>\mathrm{Mg}$ concentration in Mytilus coruscus in autumn and winter, Li et al. 2010; $\mathrm{P}>\mathrm{Ca}>\mathrm{Mg}>\mathrm{K}$ in $M$. edulis from China, Chi et al. 2012; $\mathrm{Ca}>\mathrm{K}$ concentration in M. galloprovincialis, Fatoki et al. 2012). To compare our results with data reported by other authors, the percentage of moisture were determined (digestive gland $=82.7 \pm 2.7$; gills $=87.1 \pm 1.2 ; \mathrm{RST}=83.3 \pm 2.3 ; \mathrm{OST}=86.1 \pm 2.9$ ) Regarding the concentrations detected, our results were similar to those found in this species by several authors (K, Ca and S, Santos et al. 2014; Ca, Jović et al. 2011), but different to reported by others ( $\mathrm{K}$ and $\mathrm{Ca}$, Fatoki et al. 2012; $\mathrm{Na}, \mathrm{K}, \mathrm{P}, \mathrm{Ca}$ and $\mathrm{Mg}$, Bongiorno et al. 2015). In those studies, there were different techniques to the mineral analysis (flame atomic absorption spectrophotometry, spectroquant kits by spectrophotometry, energy dispersive X-ray fluorescence and inductively coupled plasma mass spectrometry), species (M. galloprovincialis, M. coruscus, M. edulis), seasons (January to December), and locations [local markets of Valencia -mussels from Ría de Vigo (Atlantic Sea), hatchery in Delta del Ebro and Valencia Harbour (Mediterranean Sea), Gulf of Trieste (North Adriatic Sea), Boka Kotorska Bay (Montenegro-southeastern Adriatic Sea), Tagus estuary in Lisbon (Portugal), Shengsi Islands (China), markets of China, Cape Town Harbour (Atlantic Ocean and Indian Ocean)]. According Telesca et al. (2019), there are compensatory mechanisms in Mytilus species as protective

Table 1. Weight (geometric mean and standard error, grams) in mussel tissues after 7-day exposure of Cd-treatments / Peso (media geométrica y error estándar, en gramos) en tejidos de mejillón después de 7 días de exposición a tratamientos con $\mathrm{Cd}$

\begin{tabular}{lccccc}
\hline Mussel tissues & Control & $\mathrm{Cd}$ & $\mathrm{Cd}+\mathrm{Pb}$ & $\mathrm{Cd}+\mathrm{Cu}$ & $\mathrm{Cd}+\mathrm{Pb}+\mathrm{Cu}$ \\
\hline Digestive gland & $0.15 \pm 0.01$ & $0.15 \pm 0.02$ & $0.15 \pm 0.01$ & $0.13 \pm 0.01$ & $0.11 \pm 0.01$ \\
Gills & $0.31 \pm 0.01$ & $0.29 \pm 0.02$ & $0.30 \pm 0.01$ & $0.31 \pm 0.03$ & $0.23 \pm 0.03$ \\
RST & $0.73 \pm 0.02$ & $0.73 \pm 0.06$ & $0.71 \pm 0.03$ & $0.69 \pm 0.05$ & $0.74 \pm 0.03$ \\
OST & $1.19 \pm 0.04$ & $1.17 \pm 0.07$ & $1.17 \pm 0.04$ & $1.14 \pm 0.08$ & $1.08 \pm 0.07$ \\
\hline
\end{tabular}

RST $=$ Remaining soft tissues; OST $=$ Overall soft tissues 
Table 2. Concentration of macrominerals (geometric mean and standard error, $\mathbf{g} \mathbf{1 0 0} \mathbf{g}^{-1}$, wet weight) in mussel tissues after 7-day exposure of Cd-treatments / Concentración de macronutrientes (media geométrica y error estándar, g $100 \mathrm{~g}^{-1}$, peso fresco) en tejidos de mejillón después de 7 días de exposición a tratamientos con $\mathrm{Cd}$

\begin{tabular}{|c|c|c|c|c|c|}
\hline Mussel tissues & Control & $\mathrm{Cd}$ & $\mathrm{Cd}+\mathrm{Pb}$ & $\mathrm{Cd}+\mathrm{Cu}$ & $\mathrm{Cd}+\mathrm{Pb}+\mathrm{Cu}$ \\
\hline \multicolumn{6}{|l|}{ Digestive gland } \\
\hline $\mathrm{Ca}$ & $0.099 \pm 0.028$ & $0.099 \pm 0.012$ & $0.076 \pm 0.014$ & $0.100 \pm 0.014$ & $0.103 \pm 0.017$ \\
\hline $\mathrm{K}$ & $0.271 \pm 0.007$ & $0.268 \pm 0.007$ & $0.260 \pm 0.009$ & $0.260 \pm 0.008$ & $0.243 \pm 0.009^{*}$ \\
\hline $\mathrm{Mg}$ & $0.075 \pm 0.001$ & $0.078 \pm 0.002$ & $0.070 \pm 0.003$ & $0.078 \pm 0.003$ & $0.079 \pm 0.003$ \\
\hline $\mathrm{Na}$ & $0.542 \pm 0.013$ & $0.576 \pm 0.017$ & $0.518 \pm 0.022$ & $0.567 \pm 0.025$ & $0.578 \pm 0.030$ \\
\hline $\mathrm{P}$ & $0.188 \pm 0.004$ & $0.186 \pm 0.002$ & $0.191 \pm 0.004$ & $0.176 \pm 0.006$ & $0.179 \pm 0.006$ \\
\hline $\mathrm{S}$ & $0.401 \pm 0.008$ & $0.400 \pm 0.006$ & $0.441 \pm 0.014^{*}$ & $0.395 \pm 0.014$ & $0.395 \pm 0.014$ \\
\hline \multicolumn{6}{|l|}{ Gills } \\
\hline $\mathrm{Ca}$ & $0.050 \pm 0.002$ & $0.051 \pm 0.002$ & $0.048 \pm 0.005$ & $0.057 \pm 0.004$ & $0.064 \pm 0.005^{*}$ \\
\hline $\mathrm{K}$ & $0.160 \pm 0.004$ & $0.168 \pm 0.006$ & $0.167 \pm 0.003$ & $0.158 \pm 0.006$ & $0.152 \pm 0.005$ \\
\hline $\mathrm{Mg}$ & $0.109 \pm 0.002$ & $0.114 \pm 0.002$ & $0.110 \pm 0.003$ & $0.113 \pm 0.002$ & $0.111 \pm 0.003$ \\
\hline $\mathrm{Na}$ & $0.837 \pm 0.015$ & $0.829 \pm 0.023$ & $0.810 \pm 0.035$ & $0.870 \pm 0.026$ & $0.893 \pm 0.036$ \\
\hline $\mathrm{P}$ & $0.086 \pm 0.003$ & $0.093 \pm 0.004$ & $0.096 \pm 0.003^{*_{a}}$ & $0.084 \pm 0.004$ & $0.078 \pm 0.003^{\mathrm{a}}$ \\
\hline $\mathrm{S}$ & $0.227 \pm 0.004$ & $0.237 \pm 0.008$ & $0.247 \pm 0.009^{\mathrm{a}}$ & $0.222 \pm 0.006$ & $0.216 \pm 0.004^{\mathrm{a}}$ \\
\hline \multicolumn{6}{|l|}{ RST } \\
\hline $\mathrm{Ca}$ & $0.054 \pm 0.005$ & $0.057 \pm 0.004$ & $0.068 \pm 0.046$ & $0.074 \pm 0.028$ & $0.056 \pm 0.008$ \\
\hline $\mathrm{K}$ & $0.227 \pm 0.008$ & $0.221 \pm 0.006$ & $0.220 \pm 0.005$ & $0.204 \pm 0.006^{*}$ & $0.206 \pm 0.010$ \\
\hline $\mathrm{Mg}$ & $0.107 \pm 0.002$ & $0.106 \pm 0.002$ & $0.107 \pm 0.002$ & $0.108 \pm 0.003$ & $0.107 \pm 0.003$ \\
\hline $\mathrm{Na}$ & $0.567 \pm 0.013$ & $0.579 \pm 0.027$ & $0.556 \pm 0.025$ & $0.642 \pm 0.025^{*}$ & $0.623 \pm 0.021^{*}$ \\
\hline $\mathrm{P}$ & $0.097 \pm 0.003$ & $0.094 \pm 0.003$ & $0.092 \pm 0.003$ & $0.090 \pm 0.003$ & $0.087 \pm 0.004^{*}$ \\
\hline $\mathrm{S}$ & $0.284 \pm 0.010$ & $0.289 \pm 0.011$ & $0.279 \pm 0.012$ & $0.281 \pm 0.009$ & $0.297 \pm 0.011$ \\
\hline \multicolumn{6}{|l|}{ OST } \\
\hline $\mathrm{Ca}$ & $0.059 \pm 0.006$ & $0.061 \pm 0.004$ & $0.066 \pm 0.027$ & $0.075 \pm 0.018$ & $0.063 \pm 0.005$ \\
\hline $\mathrm{K}$ & $0.215 \pm 0.007$ & $0.215 \pm 0.006$ & $0.211 \pm 0.005$ & $0.198 \pm 0.006^{*}$ & $0.198 \pm 0.009^{*}$ \\
\hline $\mathrm{Mg}$ & $0.103 \pm 0.002$ & $0.106 \pm 0.001$ & $0.103 \pm 0.002$ & $0.106 \pm 0.002$ & $0.105 \pm 0.002$ \\
\hline $\mathrm{Na}$ & $0.634 \pm 0.010$ & $0.644 \pm 0.016$ & $0.619 \pm 0.023$ & $0.695 \pm 0.025^{*}$ & $0.676 \pm 0.022$ \\
\hline $\mathrm{P}$ & $0.106 \pm 0.003$ & $0.105 \pm 0.003$ & $0.105 \pm 0.003$ & $0.100 \pm 0.004$ & $0.095 \pm 0.004^{*}$ \\
\hline $\mathrm{S}$ & $0.285 \pm 0.009$ & $0.290 \pm 0.010$ & $0.292 \pm 0.008$ & $0.277 \pm 0.009$ & $0.290 \pm 0.009$ \\
\hline
\end{tabular}

RST= Remaining soft tissues; OST $=$ Overall soft tissues; ${ }^{*} P<0.05$ with respect to control group (t-Student or Mann-Whitney U test); For each element, the same small letter indicates statistically significant differences between heavy metal exposure groups (Kruskal-Wallis one-way ANOVA)

capacity to regional alterations of abiotic (like salinity and temperature) and biotic conditions (like food availability), which can be observed in shell composition. Bongiorno et al. (2015) reported fluctuations in ash contents of mussels according to season, accumulation and utilization of the energetic reserves, depending on the interaction among food availability, growth and reproduction. Thus, it is necessary a characterization of sampling location and environmental conditions for a better understanding of the biomonitoring data.

The highest concentrations of $\mathrm{Ca}, \mathrm{K}, \mathrm{P}$ and $\mathrm{S}$ were found in the digestive gland (Table 2). The gills had the highest concentration of $\mathrm{Na}$, whereas $\mathrm{Mg}$ had similar concentrations in gills and RST (higher than those found in digestive gland). Regarding tissue distribution, all these macrominerals were mainly accumulated in the RST (Table $3)$. On the other hand, the proportion between digestive gland and gill was similar in percentage, except in the case of $\mathrm{Mg}$ and $\mathrm{Na}$, where the percentage accumulated in gill was three times higher than the digestive gland one. There were no studies to compare this result, so future works could explain them.

\section{EXPOSURE GROUPS}

The element in which the most statistically significant differences were found was $\mathrm{K}$, followed by $\mathrm{Na}$ and $\mathrm{P}$, while $\mathrm{Ca}$ and $\mathrm{S}$ were the ones with the fewest differences (none in $\mathrm{Mg}$ ). The group exposed to the ternary mixture was in which there were more macrominerals with statistically significant differences with respect to control group, followed by the group exposed to the mixture $\mathrm{Cd}+\mathrm{Cu}$ and $\mathrm{Cd}+\mathrm{Pb}$, whereas in the group exposed to $\mathrm{Cd}$ no significant differences in macromineral concentrations were observed. At the tissue level, the digestive gland and the gills were where less significant differences with respect to control group were appreciated, being in RST and OST where more differences were observed.

Regarding $\mathrm{Ca}$, its concentration increased slightly $(P$ $>0.05)$ in the OST of all groups compared to the control group. In relation to the tissues, the concentration of this mineral just increased $(28 \%, P<0.05)$ in the gills of the group exposed to ternary mixture. Experimental studies in which the interference of a heavy metal on other essential elements are scarce, and even less so in the case of combined exposures. Thus, in the group exposed to $\mathrm{Cd}$, the results obtained do not agree with previous reports (Sheir $e t$ 
Table 3. Percentage of macrominerals (geometric mean and standard error) in mussel tissues after 7-day exposure of Cd-treatments / Porcentaje de macronuntrientes (media geométrica y error estándar) en tejidos de mejillón después de 7 días de exposición a tratamientos con Cd

\begin{tabular}{crrrrr}
\hline Mussel tissues & \multicolumn{1}{c}{ Control } & \multicolumn{1}{c}{$\mathrm{Cd}$} & $\mathrm{Cd}+\mathrm{Pb}$ & $\mathrm{Cd}+\mathrm{Cu}$ & $\mathrm{Cd}+\mathrm{Pb}+\mathrm{Cu}$ \\
\hline Digestive gland & & & & & \\
$\mathrm{Ca}$ & $21.11 \pm 1.39$ & $20.29 \pm 1.75$ & $14.34 \pm 2.51$ & $15.53 \pm 3.24$ & $16.48 \pm 1.29^{*}$ \\
$\mathrm{~K}$ & $15.85 \pm 0.70$ & $15.52 \pm 1.17$ & $15.44 \pm 0.74$ & $15.48 \pm 1.05$ & $12.25 \pm 1.03^{*}$ \\
$\mathrm{Mg}$ & $9.11 \pm 0.60$ & $9.19 \pm 0.76$ & $8.52 \pm 0.58$ & $8.67 \pm 0.47$ & $7.50 \pm 0.60$ \\
$\mathrm{Na}$ & $10.75 \pm 0.69$ & $11.05 \pm 0.79$ & $10.52 \pm 0.82$ & $9.62 \pm 0.59$ & $8.52 \pm 0.69^{*}$ \\
$\mathrm{P}$ & $22.30 \pm 0.72$ & $21.88 \pm 1.35$ & $22.67 \pm 0.98$ & $21.03 \pm 1.20$ & $18.97 \pm 1.16^{*}$ \\
$\mathrm{~S}$ & $17.78 \pm 0.73$ & $17.10 \pm 1.10$ & $18.91 \pm 1.35$ & $16.73 \pm 1.06$ & $13.63 \pm 1.22^{*}$ \\
$\mathrm{Gills}$ & & & & & \\
$\mathrm{Ca}$ & $22.07 \pm 1.35$ & $20.84 \pm 1.28$ & $18.68 \pm 2.36$ & $20.39 \pm 2.28$ & $21.65 \pm 1.60$ \\
$\mathrm{~K}$ & $19.38 \pm 0.61$ & $19.65 \pm 0.99$ & $20.52 \pm 1.00$ & $21.62 \pm 1.27^{\mathrm{a}}$ & $16.09 \pm 1.15^{\mathrm{a}}$ \\
$\mathrm{Mg}$ & $27.35 \pm 0.47$ & $27.22 \pm 1.54$ & $27.61 \pm 1.11$ & $28.97 \pm 1.52^{\mathrm{a}}$ & $22.16 \pm 1.67^{\mathrm{a}}$ \\
$\mathrm{Na}$ & $34.22 \pm 1.15$ & $32.09 \pm 2.17$ & $34.00 \pm 1.09$ & $34.06 \pm 1.56$ & $27.61 \pm 2.05^{*}$ \\
$\mathrm{P}$ & $21.19 \pm 0.71$ & $22.13 \pm 1.01$ & $23.47 \pm 0.93^{\mathrm{a}}$ & $23.17 \pm 1.29^{\mathrm{b}}$ & $17.43 \pm 1.03^{\mathrm{a}, \mathrm{b}}$ \\
$\mathrm{S}$ & $20.74 \pm 0.82$ & $20.46 \pm 1.12$ & $21.94 \pm 0.95^{\mathrm{a}}$ & $21.67 \pm 1.41^{\mathrm{b}}$ & $15.65 \pm 0.92^{\mathrm{a}_{\mathrm{a}, \mathrm{b}}}$ \\
$\mathrm{RST}$ & & & & & \\
$\mathrm{Ca}$ & $55.84 \pm 1.72$ & $57.72 \pm 2.06$ & $62.56 \pm 4.24$ & $58.51 \pm 5.02$ & $60.68 \pm 1.98$ \\
$\mathrm{~K}$ & $64.52 \pm 0.80$ & $64.11 \pm 1.59$ & $63.59 \pm 1.35$ & $62.15 \pm 1.28^{\mathrm{a}}$ & $70.78 \pm 1.97^{* \mathrm{a}}$ \\
$\mathrm{Mg}$ & $63.31 \pm 0.82$ & $62.76 \pm 1.97$ & $63.42 \pm 1.42$ & $61.78 \pm 1.37^{\mathrm{a}}$ & $69.38 \pm 2.07^{* \mathrm{a}}$ \\
$\mathrm{Na}$ & $54.54 \pm 1.50$ & $55.59 \pm 2.50$ & $54.92 \pm 1.61$ & $55.70 \pm 1.47$ & $62.66 \pm 2.45^{*}$ \\
$\mathrm{P}$ & $56.24 \pm 1.08$ & $55.27 \pm 1.64$ & $53.33 \pm 1.66^{\mathrm{a}}$ & $55.02 \pm 1.31$ & $62.82 \pm 2.01^{* \mathrm{a}}$ \\
$\mathrm{S}$ & $61.14 \pm 1.12$ & $61.75 \pm 1.47$ & $58.30 \pm 2.09^{\mathrm{a}}$ & $60.77 \pm 1.43^{\mathrm{b}}$ & $69.86 \pm 1.94^{\mathrm{a}, \mathrm{ab}}$ \\
\hline & & & & &
\end{tabular}

RST $=$ Remaining soft tissues; ${ }^{*} P<0.05$ with respect to control group; For each element, the same small letter indicates statistically significant differences between heavy metal exposure groups

al. 2013) on mussels of the species Mytilus edulis exposed to this metal for 8 days at a dose 5 times lower than those used in this study, which indicated that there was a decrease in Ca concentrations in both gill and digestive gland due to different tissue lesions. On the other hand, $\mathrm{Cd}$ and $\mathrm{Pb}$ are two analogue metals to $\mathrm{Ca}$, competing with it for the binding sites in the gill of the fish (Macdonald et al. 2002, Rogers et al. 2003, Playle 2004). Several studies show that this competition can carry a reduction of the $\mathrm{Ca}$ absortion (Niyogi \& Wood 2004, Rogers \& Wood 2004, Rainbow $\&$ Black 2005), leading to ionic and osmotic disturbances that contribute to the toxicity of these metals (Playle 2004). In oysters, Huanxin et al. (2000) describe that Ca is easily substituted for $\mathrm{Cd}$, even producing cellular necrosis, whereas different studies in fishes and bivalve molluscs show several alterations associated to the homeostasis and physiology of Ca (Neff et al. 1987, Sunila 1988, Orrenius et al. 1989, Schoenmakers et al. 1992, Da Ros et al. 1995). In this study, a decrease in Ca concentration were observed only in the group exposed to $\mathrm{Cd}+\mathrm{Pb}$ in digestive gland and gills, but it was not statistically significant. Regarding the differences between forms of exposure (individual vs mixtures), some studies indicate that the ionic imbalances produced by binary mixtures of $\mathrm{Cd}$ and $\mathrm{Pb}$ are greater than those caused by simple exposures (Kara 2010, Clemow et al. 2015, Van Ginneken et al. 2015), which could justify the significant imbalance of $\mathrm{Ca}$ found in gill of the groups exposed to the more complex Cd-mixture, although it would be necessary to perform new tests with different binary and ternary heavy metal mixtures to check whether it is a modulated effect by the complexity of the mixture.
In regard to the tissue distribution of $\mathrm{Ca}$ (Table 3), it can be observed that the treatments did not significantly altered the distribution of this element among tissues, with the exception of the digestive gland of the ternary mixture (decrease by $21.9 \%, P<0.05$ ), and the RST of this exposure group (increase by $8.7 \%, P=0.06$ ). Although the concentration of $\mathrm{Ca}$ in gills in this exposure group was higher than those found in the control group $(P<0.05)$, the percentage of $\mathrm{Ca}$ accumulated in this tissue over the total body was not higher than the control group. Sheir et al. (2013) reported an increase of necrosis in the digestive gland and gills after experimental exposure of $\mathrm{Cd}$, so it could cause a decrease in the weight of these tissues. Then, histological studies are necessary to understand our result.

Regarding $\mathrm{Mg}$, the concentration was very similar in all treatments, both in the OST and in each one of the analyzed tissues (Table 2). Only one study was found about $\mathrm{Mg}$ concentration in mussels exposed to heavy metal (specifically $\mathrm{Cu}$ ). In this work, Jorge et al. (2013) reported (in juvenile mussels of Lampsilis siliquoidea) no variations in tissue $\mathrm{Mg}$ concentration. About the distribution of $\mathrm{Mg}$, significant differences in tissues of the mussels exposed to the ternary mixture (compared to the control group and $\mathrm{Cd}+\mathrm{Cu}$ exposure group) were found, decreasing the percentage in gill (19.0 and $23.5 \%$ respectively) and increasing in the RST (9.6 and $12.3 \%$ respectively). It could be a consequence of the decrease in gills weight (Table 1). The Mg is an essential element which takes part in different organic and structural functions (Rosenberg \& Hughes 1991, Klein et al. 1996, Stecher et al. 1996, Aranda 
et al. 2000), and one of the most important is related to the smooth muscle of the molluscs (Hooper et al. 2008). In situations of exposure to complex mixtures such as ternary, it could be possible a redistribution of $\mathrm{Mg}$ to the compartment called RST, where the musculature of the mussel is takes place.

The concentration of $\mathrm{K}$ in the OST decreased $(P<$ $0.05)$ in the groups exposed to $\mathrm{Cd}+\mathrm{Cu}(7.9 \%)$ and to the ternary mixture $(7.9 \%)$, whereas the concentration of $\mathrm{Na}$ increased in the group exposed to $\mathrm{Cd}+\mathrm{Cu}(9.6 \%, P<0.05)$ and marginally in the group exposed to the ternary mixture $(6.6 \%, P=0.09)$. In the tissues of these same exposure groups, although the trend was the same as that observed in OST, only statistically significant differences were observed in the digestive gland (K concentration in mussels exposed to the ternary mixture, decreased by $10.3 \%$ ) and in the RST (concentration of $\mathrm{Na}$ and $\mathrm{K}$ in mussels exposed to $\mathrm{Cd}+\mathrm{Cu}$, increased by $13.2 \%$, and decreased by $10.1 \%$, respectively; concentration of $\mathrm{Na}$ in mussels exposed to the ternary mixture, increased by $9.9 \%$, and marginally significant, $P=0.06$, in the concentration of $\mathrm{K}$, decreased by $9.3 \%$ ). Other relevant observations were the no significant differences in both $\mathrm{K}$ and $\mathrm{Na}$ concentrations in gills (any exposure group), and the tendency to decrease of both $\mathrm{K}$ and $\mathrm{Na}$ concentrations in the group exposure to $\mathrm{Cd}+\mathrm{Pb}$ binary mixture (except $\mathrm{K}$ in gills). As seen, there seems to be a different behavior depending on the simultaneous presence of $\mathrm{Cu}$ and $\mathrm{Pb}$. On the other hand, the $\mathrm{Na}-\mathrm{K}$ pump is an integral membrane protein, fundamental in the physiology of the cell. Its function is the transport of the most important ions in biology, $\mathrm{Na}$ and $\mathrm{K}$, and regulates therefore, the ionic balance. Exposure to heavy metals causes ionic imbalances that can alter this equilibrium. According to some authors, metals such as $\mathrm{Cd}$ in clams (Anodonta cynegea) and fishes (Platichthys flesus) may decrease K concentrations (Larsson et al. 1981, Hemelraad et al. 1990), and metals such as $\mathrm{Cu}$ and $\mathrm{Pb}$ can inhibit the uptake of $\mathrm{Na}$ in other marine species such as Oncorhynchus mykiss and Daphnia magna (De Schamphelaere \& Janssen 2002, Grosell \& Wood 2002, Rogers et al. 2005). This could partially explain our results, because in the OST and $\mathrm{RST}$ of the groups exposed to the $\mathrm{Cd}+\mathrm{Cu}$ binary mixture and to the ternary mixture, the significant decrease in $\mathrm{K}$ concentration was clearly seen, while $\mathrm{Na}$ concentration did not decrease, but increased significantly or marginally, which could also be interpreted as an ionic imbalance. In this respect, it should be mentioned that what metals such as $\mathrm{Cd}$ and $\mathrm{Cu}$ make are to affect enzymes such as $\mathrm{Na}+/ \mathrm{K}+$-ATPase and carbonic anhydrase, both of which are involved in the uptake of $\mathrm{Na}$ in the gill (Postel et al. 1998, Atli \& Canli 2007, Birceanu et al. 2008, Jorge et al. 2013, Nogueira et al. 2013). However, in this study the concentrations of these elements in the gills of the groups exposed to $\mathrm{Cd}+\mathrm{Cu}$ and to the ternary mixture were not significantly altered, which could justify a priori an adequate functioning of these enzymes at this level and therefore, that did not decrease Na concentration. However, when the percentage distribution of these elements was evaluated (to respect to control group), a decrease in the percentage of $\mathrm{Na}(P<0.05)$ and $\mathrm{K}(P=0.06)$ in gill $(19.3$ and $17.0 \%$, respectively) and digestive gland (20.7 and $22.7 \%$, respectively) in the group exposed to the ternary mixture, and an increase $(P<0.05)$ in the RST $(14.9$ and $9.7 \%$, respectively) was observed; but an increase of the percentage of $\mathrm{K}$ in gills $(11.6 \%, P=0.08)$ in $\mathrm{Cd}+\mathrm{Cu}$ binary exposure group was found. In addition, the percentage of $\mathrm{K}$ decreased by $25.6 \%(P<0.05)$ in gills of mussels exposed to ternary group to respect $\mathrm{Cd}+\mathrm{Cu}$ exposure group, and an increase $(13.9 \%, P<0.05)$ in RST were observed. Although it is not possible to explain these results, it could be assumed that certain alterations are occurring in gill, at least in the exposure to the more complex mixture. This lead us to think of the usefulness of determining not only tissue concentrations, but also distribution of the elements in the different compartments.

Phosphorus and sulfur are two important elements in heavy metal detoxification systems in some bivalves (George \& Pirie 1979, Giambérini \& Pihan 1996, Marigómez et al. 2002). In this study, the concentration of $\mathrm{P}$ found on OST of the metal-exposed groups were similar to those of the control group, except in the mussels exposed to the ternary mixture, where they decreased by $10.4 \%$ $(P<0.05)$. In the tissues, a decrease in $\mathrm{P}$ concentration in $\operatorname{RST}(10.3 \%, P=0.05)$ and gills $(9.3 \%, P=0.08)$ of the mussels exposed to ternary mixture and an increase in gills $(11.6 \%)$ of the mussels exposed to $\mathrm{Cd}+\mathrm{Pb}(P=$ $0.05)$ with respect to control were found. In addition, a decrease of $\mathrm{P}$ concentration $(P<0.05)$ was found in gills from mussels exposed to ternary mixture with respect to $\mathrm{Cd}+\mathrm{Pb}(18.8 \%)$ exposure group. Regarding $\mathrm{S}$, no significant differences were found (with respect to control group) in the concentrations of this element on the OST nor on the tissues of the exposure groups, except in the digestive gland of the group treated with $\mathrm{Cd}+\mathrm{Pb}$ were increased by $10.0 \%$ its concentration (in the gills also there was an increase of $8.8 \%$, but marginally significant, $P=$ $0.06)$. Furthermore, $\mathrm{S}$ concentration in gills decreased $(P$ $<0.05)$ in mussels exposed to ternary mixture with respect to $\mathrm{Cd}+\mathrm{Pb}$ exposure group (12.6\%). Therefore, in the group exposed to the binary mixture $\mathrm{Cd}+\mathrm{Pb}$ there was an increase in the concentration of $\mathrm{P}$ and $\mathrm{S}$ in gill and digestive gland. In this respect, in an experimental study on pond snail (Lymnaea stagnalis), Desouky (2006) shows an increase in the amount of $\mathrm{P}$ and $\mathrm{S}$-based ligands in granules of various tissues for the sequestration of metals such as $\mathrm{Cd}$, so it can also be thought that $M$. galloprovincialis may be producing a stimulus in the synthesis of lysosomal granules based on $\mathrm{P}$ and $\mathrm{S}$ for the metal sequestration, although perhaps the 
single exposure of $\mathrm{Cd}$ was not sufficient and in the ternary mixture it occurs the failure of this process. Although this is mere speculation, it could find a possible tissue speciation in the generation of such granules: $\mathrm{P}$ in gill and $\mathrm{S}$ in gland. At the bibliographical level some publications were found that refer to the amounts of $\mathrm{P}$ in mussels as a nutritional aspect (Rivero 2006), but none about biomonitoring studies or experimental exposures in which the tissue concentration of these elements is determined. Based on this nutritional composition, the $\mathrm{P}$ concentration found in this study was within the normal range.

With respect to the distribution of $\mathrm{P}$ and $\mathrm{S}$ in the different tissue compartments, there were statistically significant differences in all the tissues of the group exposed to the ternary mixture, decreasing the percentage in gland (14.9 and $23.3 \%$ for $\mathrm{P}$ and $\mathrm{S}$ respectively) and gill (17.7 and $24.5 \%$ for $P$ and $S$ respectively), and increasing in the RST (11.7 and $14.3 \%$ for $\mathrm{P}$ and $\mathrm{S}$ respectively). In addition, $\mathrm{P}$ and $\mathrm{S}$ percentage decreased $(P<0.05)$ in gills from mussels exposed to ternary mixture to respect $\mathrm{Cd}+\mathrm{Pb}$ (25.7 and $28.7 \%$ respectively) and $\mathrm{Cd}+\mathrm{Cu}(24.8$ and $27.8 \%$ respectively) exposure groups, with an increase in RST to respect $\mathrm{Cd}+\mathrm{Pb}(\mathrm{P}=17.8 \%$, and $\mathrm{S}=19.8 \%)$ and $\mathrm{Cd}+\mathrm{Cu}$ $(\mathrm{S}=15.0 \%)$. Again, it was the more complex mixture that marked important differences, similar to response by other macrominerals.

In conclusion, it can be affirmed that the tissue composition of macrominerals is susceptible to the presence of $\mathrm{Cd}$ and heavy metal $\mathrm{Cd}$-mixtures, with percentages of changes until $28.7 \%$. This fact, together with the relative ease of obtaining this information through current analysis techniques (simultaneous detection of essential and non-essential elements), could be taken into account in all types of studies of heavy metal contamination in marine ecosystems. The study of the concentration of these elements in each of the different tissues, besides providing the information on the kinetics of them, allows to know the total amount of each element in each compartment, contributing with data that is usually not taken into consideration in field studies or in bioassays, but that have shown to be related with the presence of these pollutants.

\section{ACKNOWLEDGMents}

The authors would like to thank to Marina Albentosa, Juan Antonio Campillo, Carmen González and Francisco Gómez (Spanish Institute of Oceanography, IEO, Center of Murcia) for their invaluable help collecting samples and use of facilities and Francisco San Nicolás for the processing of the samples.

\section{LITERATURE CITED}

Albentosa M, L Viñas, V Besada, A Franco \& A GonzálezQuijano. 2012. First measurements of the scope for growth (SFG) in mussels from a large scale survey in the NorthAtlantic Spanish coast. Science of the Total Environment 435: 430-445.

Aranda P, E Planells \& J Llopis. 2000. Scientific communication: Art o technique? Ars Pharmaceutica 41(1): 91-100.

Atli G \& M Canli. 2007. Enzymatic responses to metal exposures in a freshwater fish Oreochromis niloticus. Comparative Biochemistry and Physiology Part C: Toxicology \& Pharmacology 145(2): 282-287.

Besada V, JL Sericano \& F Schultze. 2014. An assessment of two decades of trace metals monitoring in wild mussels from the Northwest Atlantic and Cantabrian coastal areas of Spain, 1991-2011. Environment International 71: 1-12.

Birceanu O, MJ Chowdhury, PL Gillis, JC McGeer, CM Wood \& MP Wilkie. 2008. Modes of metal toxicity and impaired branchial ionoregulation in rainbow trout exposed to mixtures of $\mathrm{Pb}$ and $\mathrm{Cd}$ in soft water. Aquatic Toxicology 89(4): 222-231.

Blackmore G \& WX Wang. 2002. Uptake and efflux of Cd and $\mathrm{Zn}$ by the green mussel Perna viridis after metal preexposure. Environmental Science \& Technology 36(5): 989-995.

Blažka ME \& ZA Shaikh. 1991. Differences in cadmium and mercury uptakes by hepatocytes: role of calcium channels. Toxicology and Applied Pharmacology 110(2): 355-363.

Bongiorno T, L Iacumin, F Tubaro, E Marcuzzo, A Sensidoni \& F Tulli. 2015. Seasonal changes in technological and nutritional quality of Mytilus galloprovincialis from suspended culture in the Gulf of Trieste (North Adriatic Sea). Food Chemistry 173: 355-362.

Boran M \& I Altınok. 2010. A review of heavy metals in water, sediment and living organisms in the Black Sea. Turkish Journal of Fisheries and Aquatic Sciences 10: 565-572.

Calabrese A, JR MacInnes, DA Nelson, RA Greig \& PP Yevich. 1984. Effects of long-term exposure to silver or copper on growth, bioaccumulation and histopathology in the blue mussel Mytilus edulis. Marine Environmental Research 11(4): 253-274.

Chi CF, JS Zhang, CW Wu, MY Xu \& B Wang. 2012. Trace elements compositions and fatty acid profiles of mussel. Advanced Materials Research 554/556: 1064-1067.

Clemow YH \& MP Wilkie. 2015. Effects of Pb plus Cd mixtures on toxicity, and internal electrolyte and osmotic balance in the rainbow trout (Oncorhynchus mykiss). Aquatic Toxicology 161: 176-188.

Da Ros L, C Nasci, G Campesan, P Sartorello, G Stocco \& A Menetto. 1995. Effects of linear alkylbenzene sulphonate (LAS) and cadmium in the digestive gland of mussel, Mytilus sp. Marine Environmental Research 39(1): 321-324.

De Schamphelaere KA \& CR Janssen. 2002. A biotic ligand model predicting acute copper toxicity for Daphnia magna: the effects of calcium, magnesium, sodium, potassium, and pH. Environmental Science \& Technology 36(1): 48-54. 
Desouky MM. 2006. Tissue distribution and subcellular localization of trace metals in the pond snail Lymnaea stagnalis with special reference to the role of lysosomal granules in metal sequestration. Aquatic Toxicology 77(2): 143-152.

Di Toro DM, HE Allen, HL Bergman, JS Meyer, PR Paquin \& RC Santore. 2001. Biotic ligand model of the acute toxicity of metals. 1. Technical basis. Environmental Toxicology and Chemistry 20(10): 2383-2396.

Fatoki OS, HK Okoro, FA Adekola, BJ Ximba \& RG Snyman. 2012. Bioaccumulation of metals in black mussels (Mytilus galloprovincialis) in Cape Town Harbour, South Africa. The Environmentalist 32(1): 48-57.

Feng H, W Zhang, L Zhang, XC Wang, L Yu \& D Yu. 2008. Heavy metal contamination in selected urban coastal regions in US and China. In: Sánchez ML (ed). Causes and effects of heavy metal pollution, pp. 265-286. Nova Science Publishers, Hauppauge.

Fraga CG. 2005. Relevance, essentiality and toxicity of trace elements in human health. Molecular Aspects of Medicine 26(4): 235-244.

Fraysse B, JP Baudin, J Garnier-Laplace, C Adam \& A Boudou. 2002. Effects of $\mathrm{Cd}$ and $\mathrm{Zn}$ waterborne exposure on the uptake and depuration of $57 \mathrm{Co}, 110 \mathrm{~m} \mathrm{Ag}$ and 134 Cs by the Asiatic clam (Corbicula fluminea) and the zebra mussel (Dreissena polymorpha) -whole organism study. Environmental Pollution 118(3): 297-306.

Fuentes A, I Fernández-Segovia, I Escriche \& JA Serra. 2009. Comparison of physico-chemical parameters and composition of mussels (Mytilus galloprovincialis Lmk.) from different Spanish origins. Food Chemistry 112(2): 295-302.

George SG \& BJ Pirie. 1979. The occurrence of cadmium in sub-cellular particles in the kidney of the marine mussel, Mytilus edulis, exposed to cadmium: The use of electron microprobe analysis. Biochimica et Biophysica Acta (BBA)-Protein Structure 580(2): 234-244.

Giambérini L \& JC Pihan. 1996. The pericardial glands of the zebra mussel: Ultrastructure and implication in lead detoxication process. Biology of the Cell 86(1): 59-65.

González-Fernández C, M Albentosa, JA Campillo, L Viñas, J Fumega, A Franco, V Besada, A González-Quijano \& J Bellas. 2015. Influence of mussel biological variability on pollution biomarkers. Environmental Research 137: 14-31.

Grosell M \& CM Wood. 2002. Copper uptake across rainbow trout gills mechanisms of apical entry. Journal of Experimental Biology 205(8): 1179-1188.

Hemelraad J, DA Holwerda, HJA Wijnne \& DI Zandee. 1990. Effects of cadmium in freshwater clams. I. Interaction with essential elements in Anodonta cygnea. Archives of Environmental Contamination and Toxicology 19(5): 686-690.

Hinkle PM, PA Kinsella \& KC Osterhoudt. 1987. Cadmium uptake and toxicity via voltage- sensitive calcium channels. Journal of Biological Chemistry 262(34): 16333-16337.

Hooper SL, KH Hobbs \& JB Thuma. 2008. Invertebrate muscles: Thin and thick filament structure; molecular basis of contraction and its regulation, catch and asynchronous muscle. Progress in Neurobiology 86: 72-127.
Huanxin W, Z Lejun \& BJ Presley. 2000. Bioaccumulation of heavy metals in oyster (Crassostrea virginica) tissue and shell. Environmental Geology 39(11): 1216-1226.

Iyengar GV. 1989. Element analysis of biological systems. Biomedical, environmental, conceptional, and methodological aspects of trace elements, $256 \mathrm{pp}$. CRC Press, Boca Raton.

Jorge MB, VL Loro, A Bianchini, CM Wood \& PL Gillis. 2013. Mortality, bioaccumulation and physiological responses in juvenile freshwater mussels (Lampsilis siliquoidea) chronically exposed to copper. Aquatic Toxicology 126: 137-147.

Jović M, A Stanković, L Slavković-Beskoski, I Tomić, S Degetto \& S Stanković. 2011. Mussels as a bio-indicator of the environmental quality of the coastal water of the Boka Kotorska Bay (Montenegro). Journal of the Serbian Chemical Society 76(6): 933-946.

Kara Y. 2010. Physiological and toxicological effects of $\mathrm{Pb}$ plus Cd mixtures on Rainbow Trout (Oncorhynchus mykiss) in soft acidic water. PhD Thesis, Wilfrid Laurier University, Waterloo, $137 \mathrm{pp}$.

Klein RT, KC Lohmann \& CW Thayer. 1996. Sr/ $\mathrm{Ca}$ and ${ }^{13} \mathrm{C} /{ }^{12} \mathrm{C}$ ratios in skeletal calcite of Mytilus trossulus: Covariation with metabolic rate, salinity, and carbon isotopic composition of seawater. Geochimica et Cosmochimica Acta 60(21): 4207-4221.

Korchagin VP. 1995. Effect of $\mathrm{Mg}^{2+}$ on light transmission of a suspension of myofibrils from the phase portion of the Japanese scallop (Mizuhopecten yessoensis) adductor muscle under conditions of relaxation. Biochemistry (Moscow) 60: 1277-1283.

Lall SP. 2002. The minerals. In: Halver JE \& RW Hardy (eds). Fish nutrition, pp. 259-308. Academic Press, San Diego.

Larsson Å, BE Bengtsson \& C Haux. 1981. Disturbed ion balance in flounder, Platichthys flesus L. exposed to sublethal levels of cadmium. Aquatic Toxicology 1(1): 19-35.

Li G, J Li \& D Li. 2010. Seasonal variation in nutrient composition of Mytilus coruscus from China. Journal of Agricultural and Food Chemistry 58(13): 7831-7837.

Li S, L Xie, C Zhang, Y Zhang, M Gu \& R Zhang. 2004. Cloning and expression of a pivotal calcium metabolism regulator: calmodulin involved in shell formation from pearl oyster (Pinctada fucata). Comparative Biochemistry and Physiology Part B: Biochemistry and Molecular Biology 138(3): 235-243.

Lin YC, GP Chang-Chien, PC Chiang, WH Chen \& YC Lin. 2013. Multivariate analysis of heavy metal contaminations in seawater and sediments from a heavily industrialized harbor in Southern Taiwan. Marine Pollution Bulletin 76(1): 266-275.

Liu F \& WX Wang. 2015. Linking trace element variations with macronutrients and major cations in marine mussels Mytilus edulis and Perna viridis. Environmental Toxicology and Chemistry 34(9): 2041-2050.

Liu F, DZ Wang \& XW Wang. 2012. Cadmium-induced changes in trace element bioaccumulation and proteomics perspective in four marine bivalves. Environmental Toxicology and Chemistry 31(6): 1292-1300. 
Lucu C \& DW Towle. 2003. $\mathrm{Na}^{+}+\mathrm{K}^{+}$-ATPase in gills of aquatic crustacea. Comparative Biochemistry and Physiology Part A: Molecular \& Integrative Physiology 135(2): 195-214.

Macdonald A, L Silk, M Schwartz \& RC Playle. 2002. A leadgill binding model to predict acute lead toxicity to rainbow trout (Oncorhynchus mykiss). Comparative Biochemistry and Physiology Part C: Toxicology \& Pharmacology 133(1): 227-242.

Macdonald DD, RS Carr, FD Calder, ER Long \& CG Ingersoll. 1996. Development and evaluation of sediment quality guidelines for Florida coastal waters. Ecotoxicology 5(4): 253-278.

Marigómez I, M Soto, MP Cajaraville, E Angulo \& L Giambérini. 2002. Cellular and subcellular distribution of metals in molluscs. Microscopy Research and Technique 56(5): 358-392.

McDowell LR. 2003. General introduction. In: McDowell LR (ed). Minerals in animal and human nutrition, pp. 1-32. Elsevier Science, Amsterdam.

Muneoka Y \& BM Twarog. 1983. Neuromuscular transmission and excitation-contraction coupling in molluscan muscle. In: Saleuddin ASM \& KM Wilbur (eds). The mollusca. Vol. 4. Physiology: 35-76. Academic Press, New York.

Neff JM, RE Hillman, RS Carr, RL Buhl \& JI Lahey. 1987. Histopathologic and biochemical responses in arctic marine bivalve molluscs exposed to experimentally spilled oil. Arctic 40(1): 220-229.

Niyogi S \& CM Wood. 2004. Kinetic analyses of waterborne $\mathrm{Ca}$ and $\mathrm{Cd}$ transport and their interactions in the gills of rainbow trout (Oncorhynchus mykiss) and yellow perch (Perca flavescens), two species differing greatly in acute waterborne $\mathrm{Cd}$ sensitivity. Journal of Comparative Physiology B 174(3): 243-253.

Nogueira LS, CM Wood, PL Gillis \& A Bianchini. 2013. Isolation and fractionation of gill cells from freshwater (Lasmigona costata) and seawater (Mesodesma mactroides) bivalves for use in toxicological studies with copper. Cytotechnology 65(5): 773-783.

O'Connor TP. 2004. The sediment quality guideline, ERL, is not a chemical concentration at the threshold of sediment toxicity. Marine Pollution Bulletin 49(5): 383-385.

Orrenius S, DJ McConkey, G Bellomo \& P Nicotera. 1989. Role of $\mathrm{Ca}^{+2}$ in toxic cell killing. Trends in Pharmacological Sciences 10(7): 281-285.

Playle RC. 2004. Using multiple metal-gill binding models and the toxic unit concept to help reconcile multiple-metal toxicity results. Aquatic Toxicology 67(4): 359-370.

Pond WG, DC Church, KR Pond \& PA Schoknecht. 2005. Micro- (trace) mineral elements. In: Pond WG, DB Church, KR Pond \& PA Schoknecht (eds). Basic animal nutrition and feeding, pp. 185-216. John Wiley and Sons, New York.

Popham JD \& JM D'Auria. 1982. Effects of season and seawater concentrations on trace metal concentrations in organs of Mytilus edulis. Archives of Environmental Contamination and Toxicology 11(3): 273-282.

Postel U, G Petrausch, S Riestenpatt, D Weihrauch, J Malykh, W Becker \& D Siebers. 1998. Inhibition of $\mathrm{Na}^{+} /$ $\mathrm{K}^{+}$-ATPase and of active ion-transport functions in the gills of the shore crab Carcinus maenas induced by cadmium. Marine Biology 130(3): 407-416.
Rainbow PS. 2007. Trace metal bioaccumulation: models, metabolic availability and toxicity. Environment International 33(4): 576-582.

Rainbow PS \& WH Black. 2005. Cadmium, zinc and the uptake of calcium by two crabs, Carcinus maenas and Eriocheir sinensis. Aquatic Toxicology 72(1): 45-65.

Regoli F \& G Principato. 1995. Glutathione, glutathionedependent and antioxidant enzymes in mussel, Mytilus galloprovincialis, exposed to metals under field and laboratory conditions: implications for the use of biochemical biomarkers. Aquatic Toxicology 31(2): 143164.

Rivero ÁF. 2006. Enciclopedia de los alimentos: productos del mar y de las aguas continentales (II). Distribución y Consumo 16(85): 121-143.

Roesijadi G \& ME Unger. 1993. Cadmium uptake in gills of the mollusc Crassostrea virginica and inhibition by calcium channel blockers. Aquatic Toxicology 24(3): 195-205.

Rogers JT \& CM Wood. 2004. Characterization of branchial lead-calcium interaction in the freshwater rainbow trout Oncorhynchus mykiss. Journal of Experimental Biology 207(5): 813-825.

Rogers JT, JG Richards \& CM Wood. 2003. Ionoregulatory disruption as the acute toxic mechanism for lead in the rainbow trout (Oncorhynchus mykiss). Aquatic Toxicology 64(2): 215-234.

Rogers JT, M Patel, KM Gilmour \& CM Wood. 2005. Mechanisms behind $\mathrm{Pb}$-induced disruption of $\mathrm{Na}+$ and $\mathrm{Cl}$ - balance in rainbow trout (Oncorhynchus mykiss). American Journal of Physiology-Regulatory, Integrative and Comparative Physiology 289(2): R463-R472.

Rosenberg GD \& WW Hughes. 1991. A metabolic model for the determination of shell composition in the bivalve mollusk, Mytilus edulis. Lethaia 24: 83-96

Santos I, MS Diniz, ML Carvalho \& JP Santos. 2014. Assessment of essential elements and heavy metals content on Mytilus galloprovincialis from River Tagus Estuary. Biological Trace Element Research 159(1-3): 233-240.

Schoenmakers TJ, PH Klaren, G Flik, RA Lock, PK Pang \& SEW Bonga. 1992. Actions of cadmium on basolateral plasma membrane proteins involved in calcium uptake by fish intestine. The Journal of Membrane Biology 127(3): 161-172.

Serra R, G Isani, G Tramontano \& E Carpené. 1999. Seasonal dependence of cadmium accumulation and Cdbinding proteins in Mytilus galloprovincialis exposed to cadmium. Comparative Biochemistry and Physiology Part C: Pharmacology, Toxicology and Endocrinology 123(2): 165-174.

Sheir SK, RD Handy \& TB Henry. 2013. Effect of pollution history on immunological responses and organ histology in the marine mussel Mytilus edulis exposed to cadmium. Archives of Environmental Contamination and Toxicology 64(4): 701-716.

Shi D \& WX Wang. 2004. Modification of trace metal accumulation in the green mussel Perna viridis by exposure to $\mathrm{Ag}, \mathrm{Cu}$, and $\mathrm{Zn}$. Environmental Pollution 132(2): 265277. 
Simkiss K \& KM Wilbur. 1989. Biomineralization: Cell biology and mineral deposition, 337 pp. Academic Press, San Diego.

Stecher HA, DE Krantz, CJ Lord, GW Luther \& KW Bock. 1996. Profiles of strontium and barium in Mercenaria mercenaria and Spisula solidissima shells. Geochimica et Cosmochimica Acta 60(18): 3445-3456.

Sunila I. 1988. Acute histological responses of the gill of the mussel, Mytilus edulis, to exposure by environmental pollutants. Journal of Invertebrate Pathology 52(1): 137141.

Taboada C, R Millán, I Miguez \& E Fernández-Pulpeiro. 2008. Composición en macronutrientes, aminoácidos y minerales de algunos invertebrados marinos no utilizados habitualmente como alimento. Revista Real Academia Gallega de Ciencias 27: 95-106.

Telesca L, LS Peck, T Sanders, J Thyrring, MK Sejr \& EM Harper. 2019. Biomineralization plasticity and environmental heterogeneity predict geographical resilience patterns of foundation species to future change. Global Change Biology 25(12): 4179-4193.
Van Ginneken M, M De Jonge, L Bervoets \& R Blust. 2015. Uptake and toxicity of $\mathrm{Cd}, \mathrm{Cu}$ and $\mathrm{Pb}$ mixtures in the isopod Asellus aquaticus from waterborne exposure. Science of the Total Environment 537: 170-179.

Wang WX \& PS Rainbow. 2008. Comparative approaches to understand metal bioaccumulation in aquatic animals. Comparative Biochemistry and Physiology Part C: Toxicology \& Pharmacology 148(4): 315-323.

Wang X, T Sato, B Xing \& S Tao. 2005. Health risks of heavy metals to the general public in Tianjin, China via consumption of vegetables and fish. Science of the Total Environment 350(1): 28-37.

Wilbur KM \& ASM Saleuddin. 1983. Shell formation. In: Saleuddin ASM \& KM Wilbur (eds). The mollusca. Vol. 4. Physiology: 235-287. Academic Press, London. 